\title{
MATERIALS FOR THE FINAL COVER OF SANITARY LANDFILLS
}

\author{
Davorin KOVAČIĆ \\ Faculty of Mining, Geology and Petroleum Engineering of Zagreb University, Pierottijeva 6, 41000 Zagreb, Croatia
}

Key-words: Sanitary landfill, Municipal solid waste, Final cover, Sealing layer, Compacted clay, Geomembrane, Gosynthetic clay liner, Paper mill sludge, Discarded swelling soil.

The paper deals with the selection of materials for the sealing layer in the final cover of sanitary landfills. The sealing layer is the most critical component of the final cover. Its role is to minimize percolation of water through the final cover. Materials used for the construction of the sealing layer are either of mineral origin (compacted clay) or geosynthetic (geomembrane). They are most often used in combination creating composite liners. Recently alternative materials are also used like paper mill sludge or discarded swelling clay.

\section{General}

One of the most serious problems facing urban communities today is the efficient and longterm disposal of municipal solid waste. Albeit modern technology offers extensive employment of energy and materials recovery, landfills will still be necessary for disposal of a final, unusable waste. For example the data on waste disposal practice of several large cities in the U. S. in 1984 (Pfef fer, 1992) show that higher percentage of waste is landfilled rather than incinerated.

In a recent official document of the state of the environment in the Republic of Croatia (1992) a chapter on waste management is included in which the strategy of waste management has been described. The materialization of the strategy presented in the Report ought to be carried out according to envisaged projects listed in Environmental Projects of the Republic of Croatia (1993). According to the review a number of municipal solid waste landfills are planned either as new sanitary landfills or as remedial works on old landfill sites.

Many aspects of the municipal waste disposal can be recognized as geotechnical assignments. The design and construction of landfills is an important task of a new branch of geotechnical engineering called »environmental geotechnics «. The aim of the paper is to draw attention to a particular topic of environmental geotechnics.

\section{Sanitary landfill as a geotechnical structure}

The purpose of a sanitary landfill is the isolation of the solid waste from the environment. This means that no harmful substances from the waste
Ključne riječi: Sanitarno odlagalište, Komunalni otpad, Završni pokrov, Brtveni sloj, Zbijena glina, Plastična folija, Geosintetski glineni sloj, Pulpa (otpad u proizvodnji papira), Bujajuće tlo.

U članku se razmatra izbor materijala za izradu brtvenog sloja u završnom pokrovu sanitarnih odlagališta. Brtveni sloj je kritični element završnog pokrova. Svrha ovog sloja je minimiziranje prodiranja vode kroz završni pokrov. Materijali koji se koriste za izradu brtvenog sloja su mineralnog porijekla (koherentno tlo) ili sintetski materijali (plastična folija). Oni se najčešće koriste zajedno tako da tvore kompozitni brtveni sloj. $\mathrm{U}$ novije doba koriste se $\mathrm{i}$ alternativni materijali kao npr. otpad u proizvodnji papira (pulpa) i vrste koherentnog bujajućeg tla.

body could reach the environment in unacceptable quantities.

The isolation of the waste material from the environment is achieved by providing an impermeable barrier all around the waste body. The barrier is partly constructed above the ground and partly below ground level (subsurface). The resulting structure is actually a containment which could be constructed either for the purpose of a new sanitary landfill or in the case of remedial works on the existing landfill site. The typical cross sections are shown on fig. 1.

In case of a new sanitary landfill the barrier elements are basal lining system (bottom seal) and capping system (final cover). Depending on the configuration of the site the waste could be placed on the existing groundsurface or into an excavation or depression. In both cases the bottom seal could be provided either by the subsoil with natural clay stratum or by man-made basal lining system.

In case of the treatment of an existing old landfill the task of geotechnical engineer is to create an impermeable box. The side barrier is most often slurry trench cut-off wall. Bottom seal is achieved by means of an low-permeability stratum.

In both cases capping system remains a common, visible element which is also termed final. cover. The capping system normally consists of several layers: restoration layer, drainage layer, sealing layer, gas-venting layer, regulating layer. Typical cross section (Daniel, 1993; GLR, 1993 ) is given on fig. 2.

The functions of the capping system elements are briefly mentioned hereafter. 


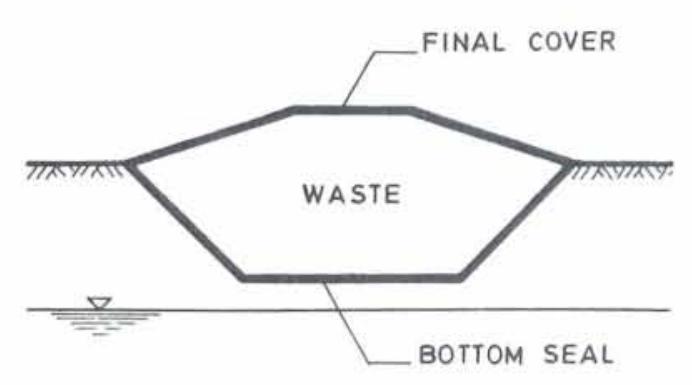

a) New sanitary landfill

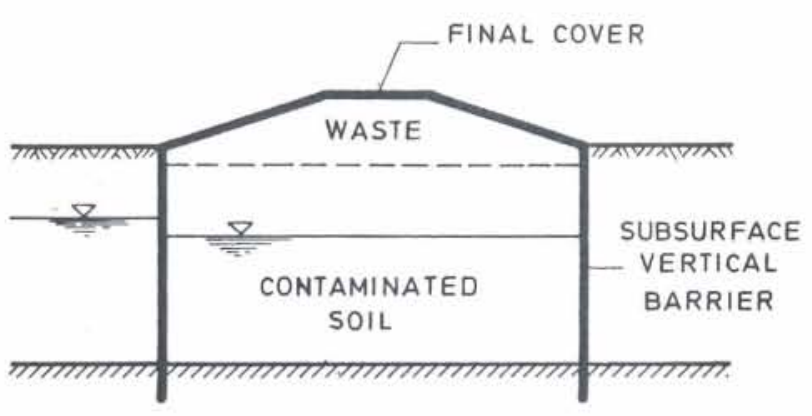

LOW-PERMEABILITY STRATUM

b) Existing landfill site

Fig. 1. Typical cross sections of sanitary landfills

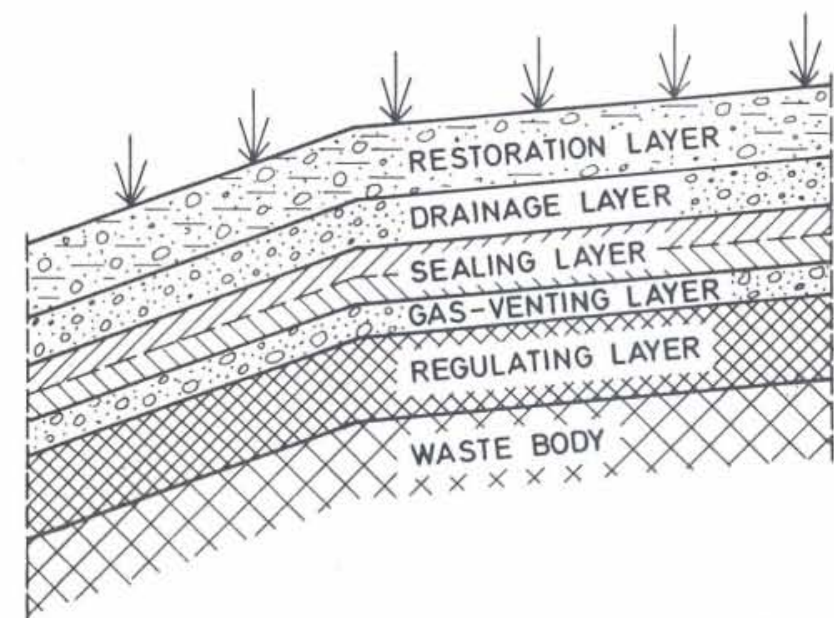

Fig. 2. Possible components of the capping system (After Daniel, 1993)

\section{Restoration layer}

The function of the restoration layer is to protect underlying layers (specially sealing layer) from frost, desiccation, root penetration, burrowing animals etc. This task of the restoration layer is achieved by the appropriate characteristics of the layer itself and by the existence of vegetation which should minimize erosion and reduce infiltration by evapo-transpiration.

\section{Drainage layer}

A drainage layer should be placed in order to drain the overlying restoration layer and to reduce the head of water on the sealing layer which minimizes infiltration into the landfill.

\section{Sealing layer}

The sealing layer is the most critical component of a capping systen. The sealing layer minimizes percolation of water through the capping system directly by impeding infiltration through the capping system directly by impeding infiltration through it and indirectly by promoting storage or drainage of water in the overlying layers.

Gas-venting layer

The purpose of a gas-venting layer is to collect gas for processing or discharge.

\section{Regulating layer}

The purpose of a regulating layer is to serve as a foundation for the overlaying sealing layer.

The following chapters will consider the various types of material which can be used for the construction of a sealing layer.

\section{Mineral sealing - compacted cohesive soil}

In a study of possible sources of natural materials for landfill liners in Great Britain, Jones et al. (1993) introduced the term "suitable « material within the general requirement of permeability $\mathrm{k}<1 \times 10^{-9} \mathrm{~m} / \mathrm{s}$. They used the suitability criteria laid down by the National Rivers Authority (NRA). The NRA defines suitable materials as those clays with following characteristics:

$$
\begin{array}{ll}
\text { - liquid limit } & <90 \% \\
\text { - plasticity index } & <65 \% \\
\text { - percentage fines } & >10 \%
\end{array}
$$

The compaction tests carried out on six types of clay within the same study (Murray et al. 1992) produced the relationship between permeability at optimum water content and plasticity index. The results set the lower limit of plasticity index to $12 \%$ as marked permeability increase was detected for plasticity indices below $12 \%$ to $15 \%$.

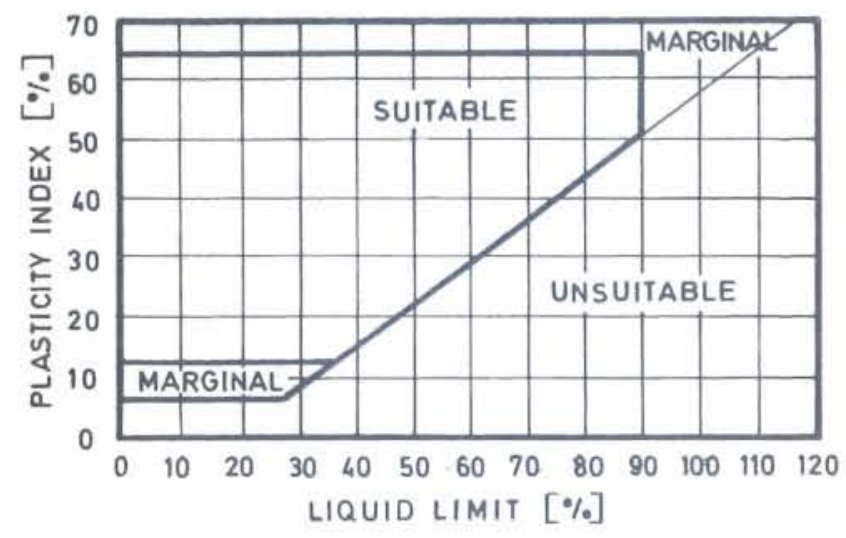

Fig. 3. Plasticity and suitability of materials according to NRA (From Jones et al. 1993)

In a review of German landfill lining systems Bishop et al. (1993) state that the chosen soil materials must fulfill the following requirements:

$$
\begin{array}{ll}
\text { - percentage fines } & >20 \% \\
\text { - organic content } & <5 \% \\
\text { - carbonate content } & <15 \% \\
\text { - dry density } & >95.5 \% \text { of Proctor maximum. }
\end{array}
$$


Among the additional requirements the authors state that the water content must remain above the Proctor optimum. An overall requirement of German regulations is that the sealing layer should be a combination of geomembrane and clay. The clay should have a permeability $\mathrm{k}<5 \times 10^{-10}$ $\mathrm{m} / \mathrm{s}$.

\section{Geomembrane}

A geomembrane can be defined as a thin, flexible, continuous, fluid-impermeable synthetic or bitumenuous based product (GLR, 1993). Geomembranes have been used extensively as effective lining system in several engineering assignments like: heap leach pads ans tailings dams (mining engineering), leaking tanks (oil and chemical industry), aquaculture lining systems and sanitary landfills.

The main purpose of geomembranes in a landfill lining system is to act as a fluid and gas barrier. In addition the geomembrane for landfill capping systems should be capable of withstanding local differential settlement.

Two types of manufactured geomembranes are: - synthetic geomembrane, plastomeric (e. g. PVC-P, HDPE) or elastomeric (e. g. EPDM),

- bituminous geomembranes, with oxidised bitumens or bitumen modified by the introduction of polymers such as EVA or SBS.

Typical characteristics of a HDPE geomembrane are:

$\begin{array}{lcc}\text { - density } & 1000 & \mathrm{~kg} / \mathrm{m}^{3} \\ \text { - tensile strength at yield } & 16,5 \mathrm{~N} / \mathrm{mm}^{2} \\ \text { - tensile strength at break } & 27,5 \mathrm{~N} / \mathrm{mm}^{2} \\ \text { - elongation at yield } & 13 \% \\ \text { - elongation at break } & 300 \%\end{array}$

According to GRL (1993) the geomembrane should have the thickness of at least $1 \mathrm{~mm}$.

\section{Composite liners}

As already mentioned, individual compacted clay liners and geomembranes are rarely used. Instead composite geomembrane/clay liners are used.

Composite liners may consist of a single or double composite liner. In either case the geomembrane is nearly always placed above the clay, although other arrangements are also possible.

Calculated flow rates through the composite liner are typically at least 100 times less than through the geomembrane or clay liner alone (Dani el, 1991).

\section{Geosynthetic clay liners}

A geosynthetic clay liner consists of a thin layer of clay (typically bentonite) sandwiched between two geotextiles or attached to a geomembrane. The primary purpose of the geosynthetic component or components is to hold the bentonite toget- her in a uniform layer and permit transportation and installation of the material without loosing bentonite or altering the thickness of the bentonite (Daniel, 1993).

The reason for the use of geosynthetic clay liners in capping systems is the exixtence of several defficiencies which make the long-term performance of a compacted clay liner questionable. These problems can be summarized as follows (Daniel, 1993):

- difficulties in compaction on a soft foundation (i. e. waste),

- tendency to desiccation and cracking without adequate protection,

- vulnerability to damage from freezing and compulsory protection from freezing by suitably thick layer of cover soil,

- differential settlement of underlying compressible waste will cause cracking in compacted clay if tensile strains become excessive,

- compacted clay liners are difficult to repair if they are damaged.

It is interesting to note that geosynthetic clay liners are not covered in GRL (1993). The explicit statement says: «...geosynthetic products, in which the lining function relies solely on the use of clayey materials (e. g. bentonite), are not considered in this recommendation due to different sealing mechanisms compared to geomembranes."

\section{Paper mill sludge}

The elevating cost of landfilling has initiated the research for the possibility of the application of unconventional materials for sealing layer. In this chapter the use of a possible alternative is described.

Zimmie et al. (1993) reported on the research which was performed in order to determine the geotechnical properties of a paper mill sludge used for Hubbardston municipal landfill in Houston, Massachussets, U. S. A. The sludge was composed of approximately $50 \%$ kaolinite and $50 \%$ organics.

The research proved that the paper mill sludge behaves similarly to a highly organic clay. It is characterised by a high water content, high compressibility and high Atterberg limits. The reported properties are as follows:

$$
\begin{array}{lr}
\text { - liquid limit } & 285 \% \\
\text { - plastic limit } & 94 \% \\
\text { - plasticity index } & 181 \% \\
\text { - initial water content } & 206 \% \\
\text { - initial void ratio } & 3.85 \\
\text { - compression index } & 1.24
\end{array}
$$

The results of the laboratory compaction tests (fig 4) yielded a skewed Proctor curve (unlike typically symmetrical bell-shaped curve) with only a small range of water contents on the dry of optimum side of the curve and with a wide range of water contents $(50-250 \%)$ on the wet of optimum part of the curve. The maximum dry density of cca. $800 \mathrm{~kg} / \mathrm{m}^{3}$ and optimum water content of cca. $50 \%$ was found. In order to point out the unusual 


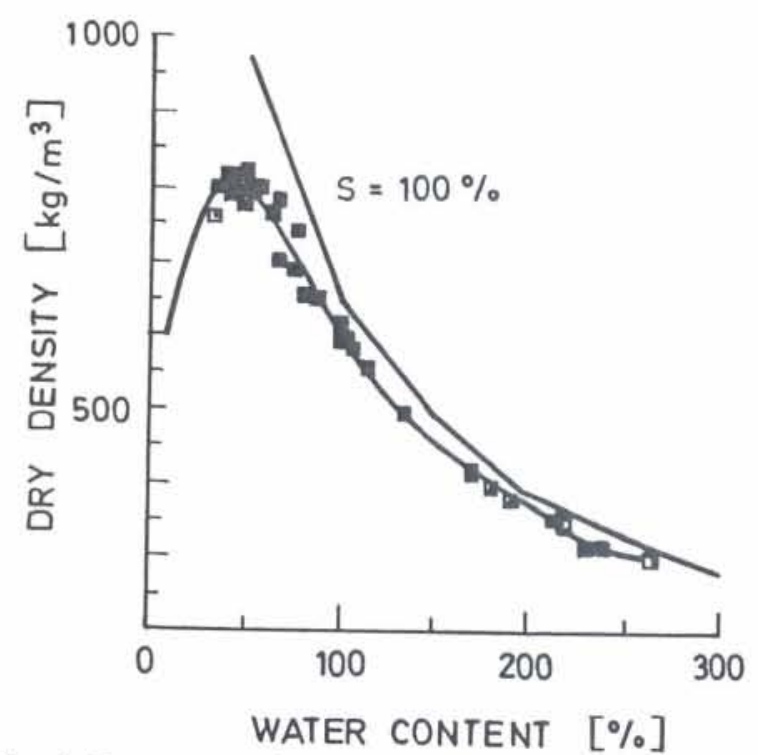

Fig. 4. Proctor curve for paper mill sludge (From Zimmie et al. 1993)

features of the paper mill sludge it should be noted that typical values for clays, both dry density and water content, are one order of magnitude less than those shown on fig. 4.

The results of laboratory permeability tests at various water contents are shown on fig. 5 . The general relationship between permeability and water content have been established by a number of studies; e. g. Mitchell et al. (1965), Daniel et al. (1990) etc. in which the minimum permeability for clays typically occurs near the optimum water content. But the curve on fig. 5 shows that permeability is increased for two orders of magnitude if water content is doubled.

Observations of the Hubbardston landfill have indicated that paper mill sludge can provide an adequate sealing layer.

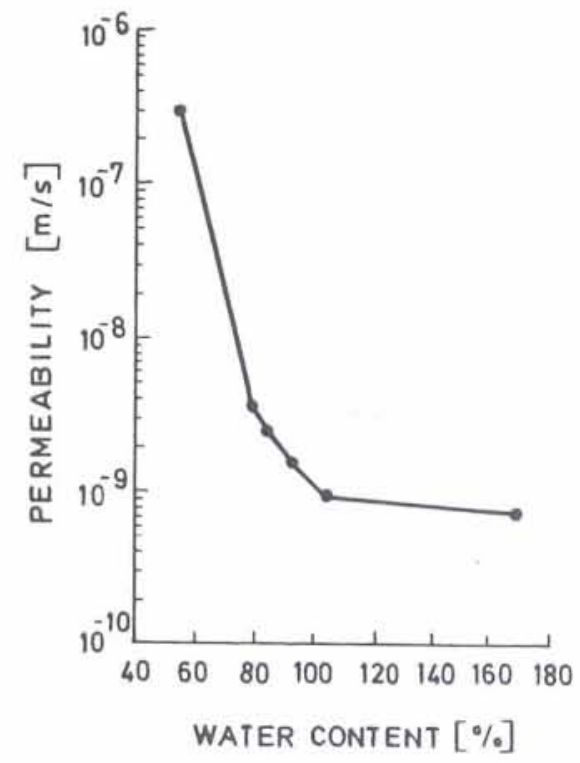

Fig. 5. Permeability vs. water content (From Zimmie et al. 1993)

\section{Discarded swelling soil}

Another example of the application of unconventional materials for the sealing layer is the use of excavated unwanted swelling soils. El-Sohby et al. (1993) carried out the investigations of the expansive soil formation in a new suburb area of Cairo. The soil excavated to a considerable depth for the foundations of a new buildings were considered as undesired waste material.

The soil was mainly composed of $53 \%$ clay, $45 \%$ silt and $2 \%$ sand. The clay fraction was mainly composed of mixed layers of montmorillonite and vermiculite. Atterberg limits were found to be:

$$
\begin{array}{ll}
\text { - liquid limit } & 80 \% \\
\text { - plastic limit } & 28 \% \\
\text { - shrinkage limit } & 15 \% \\
\text { - plasticity index } & 52 \%
\end{array}
$$

The average maximum dry density of the compacted sample was $1720 \mathrm{~kg} / \mathrm{m}^{3}$ and the optimum moisture content was $17 \%$.

Permeability was measured in the laboratory during oedometer tests. The values of the coefficient of permeability ranged between $0,4 \times 10^{-11}$ $\mathrm{m} / \mathrm{s}$ and $7 \times 10^{-11} \mathrm{~m} / \mathrm{s}$ depending on the applied pressure. These results indicate that the tested soil could serve as a sealing layer.

In addition the swelling properties of the soil should enhance its ability as a sealer. Namely, any increase in moisture content after placement in the field will cause expansion of soil which clogs the pores and reduce its permeability.

The verification of the swelling clay behaviour in the field were not reported.

\section{Conclusion}

The final cover is an important barrier element of a municipal solid waste landfill in both cases: new sanitary landfill or treatment of old landfill site. The sealing layer is the most critical component of the final cover. The material(s) for the sealing layer must be selected in accordance with regulatory standards and economic constraints, in order to minimize percolation of water into waste body which in turn should reduce the quantitiy of leachate in waste body.

The designer of a sanitary landfill can use a variety of materials for the sealing layer: natural, synthetic or waste materials as alternative solution.

In planning for waste disposal operations in developing countries the geotechnical engineering approach should aim at minimum cost solutions by using unconventional materials like paper mill sludge, discarded sweeling soil, etc.

\footnotetext{
Received: 8. II. 1994.

Accepted: 9. VI. 1994.
}

\section{REFERENCES}

Bishop, D. J. \& Carter, G. (1993): Waste disposal by landfill - German landfill lining systems. GREEN' 93 - An international symposium on Geotechnics Related to the Environment, Bolton. Balkema, Rotterdam. 
Daniel, D. E. (1991): Compacted Clay and Geosynthetic Clay Linings. Conferenze di Geotecnica di Torino, XV Ciclo, Torino

Daniel, D. E. (1993): Pollution Prevention in Landfills Using Engineered Final Covers. GREEN '93 - An international symposium on Geotechnics Related to the Environment, Bolton, Balkema, Rotterdam.

Daniel, D. E. \& Benson, C. H. (1990): Water Content Density Criteria for Compacted Soil Liners. Journal of Geotechnical Engineering, A. S. C. E., Vol 116, No. 12, $1811-1830$

E1-Sohby, M. A., Elleboudy, A. M. \& El-Bakey, M. T. (1993): Utilization of expansive soils for lining of waste disposal landfills. GREEN '93 - An international symposium on Geotechnics Related to the Environment, Bolton, Balkema, Rotterdam.

Jones, R. M., Murray, E. J., Rix, D. W. \& Humphrey, R. D. (1993): Selection of clays for use as landfill liners. GREEN '93 - An international symposium on Geotechnics Related to the Environment, Bolton, Balkema, Rotterdam.

Mitchell, J. K., Hooper, D. R. \& Campannella, R. G. (1965): Permeability of Compacted Clay. Journal of the Soil Mechanics and Foundations Division, A. S. C. E., Vol 91, No 4, 41-65.
Murray, E. J., Rix, D. W. \& Hamphrey, R. D. (1992): Clay linings to Landfill sites. Quarterly Journal of Engineering Geology, Vol. 25, No. 4, 371-376.

Pfeffer, J. T. (1992): Solid Waste Management Engineering. Prentice Hall, Englewood Cliffs 307 pp, New Jersey.

Zimmie, T. F., Moo-Young, H. \& LaPlante, K. (1993): The Use of Waste Paper Sludge for Landfill Cover Material. GREEN '93 - An international symposium on Geotechnics Related to the Environment, Bolton, Balkema, Rotterdam.

- (1992): National Report on Environment and Development, Republic of Croatia, Ministry of Environmental Protection, Physical Planning and Housing, 52 pp, Zagreb.

- (1993): Environmental Protection Projects of the Republic of Croatia, Ministry of Civil Engineering and Environmental Protection, $188 \mathrm{pp}$, Zagreb.

- (1993): Geotechnics of Landfill Design and Remedial Works Technical Recommendations - G L R, Second Edition, Ernst \& Sohn, $158 \mathrm{pp}$. Berlin. 